\title{
Evaluation of transcutaneous carbon dioxide and saturation monitoring during fiberoptic bronchoscopy
}

Merve YUMRUKUZ

ŞENEL ${ }^{1}$ (ID)

Hikmet FIRAT $^{2}$ (ID)

Emine Bahar KURT ${ }^{2}(\mathrm{ID})$
Cite this article as: Yumrukuz Şenel M, Fırat $H$, Kurt EB. Evaluation of transcutaneous carbon dioxide and saturation monitoring during fiberoptic bronchoscopy. Tuberk Toraks 2020;68(4):379-387.

Yazışma Adresi (Address for Correspondence)

Dr. Merve YUMRUKUZ ŞENEL

Balıkesir Devlet Hastanesi,

Göğüs Hastalıkları Kliniği,

BALIKESIR - TÜRKIYE

e-mail: mryumrukuz@gmail.com

CCopyright 2020 by Tuberculosis and Thorax.

Available on-line at www.tuberktoraks.org.com
${ }^{1}$ Clinic of Chest Diseases, Balıkesir State Hospital, Balıkesir, Turkey

${ }^{1}$ Balıkesir Devlet Hastanesi, Göğüs Hastalıkları Kliniği, Balıkesir, Türkiye

${ }^{2}$ Department of Chest Diseases, University of Health Sciences, Ankara Diskapi Yildirim Beyazit Research and Training Hospital, Ankara, Turkey

${ }^{2}$ Sağlık Bilimleri Üniversitesi, Ankara Dışkapı Yıldırım Beyazıt Eğitim ve Araştırma Hastanesi, Göğüs Hastalıkları Kliniği, Ankara, Türkiye

\begin{abstract}
Evaluation of transcutaneous carbon dioxide and saturation monitoring during fiberoptic bronchoscopy

Introduction: The aim of the study was to assess the effects of interventions during bronchoscopy on ventilation and determine the risk factors for hypoventilation related to both interventions and patients' demographical and clinical characteristics.
\end{abstract}

Materials and Methods: A total of 74 patients who underwent fiberoptic bronchoscopy $(F O B)$ were included in the study. Oxygen saturation $\left(\mathrm{SpO}_{2}\right)$ and partial carbon dioxide pressure $\left(\mathrm{PCO}_{2}\right)$ were measured transcutaneously $\left(\mathrm{TCSO}_{2}\right.$ and $\mathrm{TCPCO}_{2}$ ) using a sensor consisting of a probe placed on the earlobe. The demographic characteristics and basal, mean, peak and minimum values of $\mathrm{TCSO}_{2}$ and $\mathrm{T}_{\mathrm{C}} P \mathrm{CO}_{2}$ during $\mathrm{FOB}$ were retrospectively analyzed and assessed in terms of the risk factors for hypoventilation.

Results: During the procedure, the device automatically recorded the $\mathrm{TCSO}_{2}$ and $T_{C} P \mathrm{CO}_{2}$ values. The mean $T_{C} P C O_{2}$ level was $37.09 \pm 5.6$ (27.1-60.6) $\mathrm{mmHg}$. The mean increase in the $T_{C} P C \mathrm{O}_{2}$ level from baseline was $3.25 \pm 2.12$ $\mathrm{mmHg}$. The mean $\mathrm{TCSO}_{2}$ measurement was $95.9 \pm 2.27$ (80-100\%). The measured mean and peak $T_{C} P C O$, values were significantly higher in men. In the whole group, the patients with a history of smoking more than 20 packyears also had significantly higher $T_{C} P C_{2}$ values compared to the nonsmokers and light smokers. In the patients with endobronchial lesions, the decrease in the $\mathrm{TCSO}_{2}$ level was higher during FOB $(p=0.03)$, and the mean difference between the lowest and mean $\mathrm{TCSO}_{2}$ levels was significantly greater (6.2 vs $4.55 \%, p=0.03)$.

Conclusion: Changes in ventilation during FOB have multifactorial causes. The best indicator of ventilation is $\mathrm{PCO}_{2}$, and monitorization of $\mathrm{PCO}_{2}$ is very 
important in detecting hypoventilation. In this study, we determined some risk factors for hypoventilation in order to predict ventilation problems in patients planned to undergo FOB. We recommend that in male patients with endobronchial lesions, those with a longer smoking history, and those with a longer duration of $\mathrm{FOB}, \mathrm{SpO}_{2}$ should be monitored together with $\mathrm{PCO}_{2}$.

Key words: Bronchoscopy; saturation; ventilation

\section{ÖZ}

\section{Fiberoptik bronkoskopi sırasında transkütanöz karbondioksit ve saturasyon monitorizasyonunun değerlendirilmesi}

Giriş: Çalışmamızda, bronkoskopi sırasında uygulanan işlemlerin ventilasyon üzerine olan etkileri ile hastanın klinik ve demografik verileri ile ilişkili hipoventilasyon için risk faktörlerinin belirlenmesi amaçlanmıştır.

Materyal ve Metod: Çalışmaya fiberoptik bronkoskopi (FOB) işlemi yapılan 74 hasta dahil edilmiştir. Oksijen saturasyonu (SpO ${ }_{2}$ ) ile parsiyel karbondioksit basıncı $\left(\mathrm{PCO}_{2}\right)$ transkütanöz olarak $\left(\mathrm{TCSO}_{2}\right.$ ve $\left.T_{C} P C \mathrm{O}_{2}\right)$ kulak memesine yerleştirilen bir prob aracilığı ile ölçüm yapan alet ile ölçülmüştür. Hastaların demografik özellikleri ile FOB sırasında kaydedilmiş olan bazal, ortalama, en yüksek ve en düşük $\mathrm{TCSO}_{2}$ ve $\mathrm{TC}_{\mathrm{C}} \mathrm{CO}_{2}$ değerleri retrospektif olarak incelenmiş ve hipoventilasyona neden olabilecek risk faktörleri değerlendirilmiştir.

Bulgular: işslem sırasında ölçülen ortalama TCPCO, $37.09 \pm 5.6$ (27.1-60.6) mmHg olup, değişimi $3.25 \pm 2.12$ mmHg (artarak) olarak bulundu. Ortalama $\mathrm{TCSO}_{2}$ değeri \% $95.9 \pm 2.27$ (80-100) olarak saptandı. İzlenen ortalama ve en yüksek $T_{C} P C \mathrm{O}_{2}$ değerlerinin erkeklerde daha yüksek olduğu saptandı. Tüm grupta sigara öyküsü 20 paket-yıl üstü olanlarda TCPCO değerleri, daha düşük miktarlarda içen ve hiç içmemişlere göre daha yüksek bulundu. FOB'da endobronşial lezyonu olan hastalarda $T_{C} S_{2}$, düzeyleri işlem sırasında daha düşük saptandı ( $p=0.03$ ); ortalama $T_{C} S_{2}$ ile en düşük $T_{C} S_{2}$ arasındaki ortalama fark endobronşial lezyonu olan hastalarda daha yüksek görüldü (\%6.2 ve 4.55; $p=0.03$ ).

Sonuç: Fiberoptik bronkoskopi sırasında gelişen ventilasyon değişiklikleri multifaktöryel bir olaydır. Ventilasyonun en iyi göstergesi $\mathrm{PCO}_{2}$ 'dir ve özellikle gelişen hipoventilasyonu saptamak adına $\mathrm{PCO}_{2}$ monitorizasyonunun önemi aşikardır. Yaptığımız çalışmanın sonucunda $F O B$ işlemine girecek hastalarda gelişebilecek ventilasyon problemlerini öngörmek için bazı risk faktörleri belirlenmiştir. Özellikle FOB işlemi uzun süren, endobronşiyal lezyonu olan, erkek cinsiyette ve sigara içmiş hastalarda $\mathrm{SpO}_{2}$ ile birlikte $\mathrm{PCO}_{2}$ izleminin yapılması tarafımızca önerilmektedir.

Anahtar kelimeler: Bronkoskopi; saturasyon; ventilasyon

\section{INTRODUCTION}

Fiberoptic bronchoscopy (FOB) is one of the most frequently used procedures for the visual examination of the bronchial tree for diagnostic and therapeutic purposes. FOB is a safe procedure with a complication rate of approximately $0.1 \%$ (1). However, during $\mathrm{FOB}$, there is a risk for the patient to get hypoventilated due to several mechanisms, including upper airway obstruction, sedatives given before the intervention, and ventilation-perfusion mismatch related to the procedure itself (2). The best indicator for hypoventilation is partial carbon dioxide pressure $\left(\mathrm{PCO}_{2}\right)$, and arterial oxygen saturation $\left(\mathrm{SaO}_{2}\right)$ alone is not able to predict ventilation problems (3).

During FOB, although hypoxemia can be detected by an oximeter, the best indicator of ventilation, $\mathrm{PCO}_{2}$, cannot be easily determined (1). Without any oxygen support, oxygen desaturation can suddenly occur under conscious sedation. In these cases, a pulse oximeter is a useful tool to detect ventilation abnormalities (4). In many interventional pulmonology clinics, oxygen is routinely applied to these patients during bronchoscopy. However, due to the oxygen dissociation curve, alveolar carbon dioxide pressure increases just before the patient gets significant hypoxemia. In addition, in patients under oxygen support, carbon dioxide retention can develop, and therefore the possibility of respiratory insufficiency findings must always be kept in mind (5).

Arterial blood gas analysis is the gold standard method to measure the blood carbon dioxide level, but researchers have attempted to develop alternative methods since this analysis not only has certain side effects, including pain and risk of thrombosis but it is also expensive and cannot be used to monitor the changes in values (6). Currently, carbon dioxide pressure measurements with a cutaneous digital sensor are reported to be well correlated with the results of an arterial blood gas analysis (7-9). Previous studies have investigated the transcutaneous monitoring of $\mathrm{PCO}_{2}$ during some medical procedures. A study conducted by Heuss et al. showed increased $\mathrm{PCO}_{2}$ levels during thoracoscopy and colonoscopy (10). In another study, patients were monitored during FOB to evaluate the feasibility of transcutaneous measurement in determining ventilation problems (1). 
Different from these previous studies, we performed arterial blood gas measurements as reference to determine the accuracy and correlation of automatic transcutaneous measurements by the device.

The purpose of the study was to monitor oxygen saturation $\left(\mathrm{SpO}_{2}\right)$ and $\mathrm{PCO}_{2}$ levels during $\mathrm{FOB}$, determine the alterations in these levels under local anesthesia and sedation, assess the effects of interventions and duration of bronchoscopy on ventilation, and identify the risk factors for hypoventilation related to both interventions in line with the patients clinical and demographical characteristics. We also aimed to investigate the correlation between the $\mathrm{SpO}_{2}$ and $\mathrm{PCO}_{2}$ values obtained by an arterial blood gas analysis and the transcutaneous measurements of these values by a dedicated device.

\section{MATERIALS and METHODS}

A chart review was conducted on 81 patients aged over 18 years, who were referred to the interventional pulmonology clinic for FOB between June 2015 and June 2016. A total of 81 patients' medical records were retrospectively analyzed. Patients with severe chronic obstructive pulmonary disease (COPD), who were found to have an $\mathrm{SaO}_{2}$ value of $\leq 90 \%$ and/or arterial carbon dioxide pressure $\left(\mathrm{PaCO}_{2}\right)$ of $>50$ $\mathrm{mmHg}$ before $\mathrm{FOB}$, were excluded. In addition, due to the increased hypoventilation risk, obese patients [body mass index $(\mathrm{BMI}) \geq 30$ ] were also excluded. Lastly, the patients with missing medical records were not included in the study. After applying these exclusion criteria, the sample consisted of 74 patients. The study was approved by the local ethical committee (33/02) and conducted in accordance with the principles of the Declaration of Helsinki. Informed consent was obtained from each participant.

The blood pressure and body temperature values of the patients were evaluated before the procedure, and all were in the normal ranges. The operating room temperature was maintained at $24^{\circ} \mathrm{C}$ using an air conditioner.

The baseline demographic data, smoking history, comorbidities, and FOB indications were recorded. FOB was performed with an Olympus $\mathrm{CV}-200^{\circledR}$ device. The pulmonary function test was conducted using Jaeger MasterLab Pro ${ }^{\circledR}$. We also examined the initial chest radiographs and chest computed tomography scans and noted the presence of any pleural effusion and/or mass.
Prior to FOB, we transcutaneously measured oxygen saturation and partial carbon dioxide pressure $\mathrm{TCSO}_{2}$ and $\mathrm{TCPCO}_{2}$ ), sampled arterial blood gas simultaneously, and compared the values obtained with these two methods. The probe of the device ( $v$-Sign-sensor; SenTec AG, Therwil, Switzerland) was placed on the earlobe of the patients to monitor and record the $\mathrm{TcSO}_{2}$ and $\mathrm{TcPCO}_{2}$ values continuously throughout the procedure. The mean, lowest and highest values of $\mathrm{TcSO}_{2}$ and $\mathrm{TcPCO}_{2}$ were calculated by the device automatically. The patients were premedicated with intramuscular $5 \mathrm{mg}$ midazolam and local lidocaine before FOB. The duration of the procedure and interventions were also noted. The duration of the procedure was recorded as the time between inserting the fiberoptic bronchoscope through the nasal/oral passage and the removal of the bronchoscope.

The statistical analysis was performed employing $R$ 3.3.2 for Windows. The quantitative data were presented as mean \pm standard deviation (min-max) and the qualitative data as number and percentages. The Kolmogorov-Smirnov test revealed that the data were normally distributed; thus, we performed Student's t-test to compare ventilation parameters between the subgroups. In order to evaluate the quality of data and accuracy, the carbon dioxide and saturation values measured by the device and the results of the arterial blood gas analysis were compared. A linear regression analysis was performed to determine the correlation between the variables, and the $R^{2}$ and $p$ values were interpreted. The receiver operating characteristic (ROC) curve analysis was used to determine the cut-off, area under curve (AUC), sensitivity and specificity values for the duration of $\mathrm{FOB}$ in predicting hypoventilation $\left(\mathrm{TcSO}_{2} \leq 90 \%\right)$. A value of $\mathrm{p}<0.05$ was considered as statistically significant.

\section{RESULTS}

In this study, the data of 81 patients were collected but 7 were not found to be eligible, and therefore excluded from the study. One of these 7 patients had a BMI of $\geq 30$ and the remaining 6 had incomplete medical records. Of the 74 patients enrolled in the study, 50 were male and 24 were female. The mean age of the patients was $61 \pm 13.43$ (27-91) years. The clinical and demographic data of the patients are shown in Table 1. All the patients were treated with oxygen via cannula during the procedure, and none developed severe respiratory depression that led to the termination of the procedure. The most common 


\section{Table 1. Patients' clinical and demographic data}

\begin{tabular}{|c|c|}
\hline \multicolumn{2}{|l|}{ Characteristics } \\
\hline Age, (mean $\pm \mathrm{SD})$ (years) (range) & $61.05 \pm 13.43(27-91)$ \\
\hline \multicolumn{2}{|l|}{ Gender, n (\%) } \\
\hline Male & $50(67.56)$ \\
\hline Female & $24(32.44)$ \\
\hline \multicolumn{2}{|l|}{ Smoking history, n (\%) } \\
\hline Never smoked & $27(36.49)$ \\
\hline$<20$ pack-years & $9(12.16)$ \\
\hline$\geq 20$ pack-years & $38(51.35)$ \\
\hline \multicolumn{2}{|c|}{ Arterial blood gas values (mean \pm SD) } \\
\hline $\mathrm{PaCO}_{2}(\mathrm{mmHg})$ & $37.22 \pm 4.66$ \\
\hline $\mathrm{SaO}_{2}(\%)$ & $96.94 \pm 2.46$ \\
\hline
\end{tabular}

indication for FOB was suspicion of malignancy $(\mathrm{n}=$ $58,78.4 \%$ ) based on the presence of abnormal findings in imaging modalities, including masses, nodules, or pleural effusion. Six $(8.1 \%)$ of the patients underwent FOB for tuberculosis, 2 (2.7\%) for hemoptysis, and $8(10.8 \%)$ for other reasons. The mean duration of the procedure was $19.5 \pm 8.3$ (5-45) minutes. Among the 74 patients, bronchial lavage and biopsy were performed in $41 \%$, bronchial lavage and brushing in $27 \%$, only bronchial lavage in $27 \%$, brushing and biopsy in $2 \%$, and control bronchoscopy without any intervention in $3 \%$.

In order to evaluate the correlation between the device measurements and arterial blood gas analysis as the gold standard method, we took an arterial blood gas sample from the patients before $\mathrm{FOB}$ and simultaneously recorded the $\mathrm{TCSO}_{2}$ and $\mathrm{TCPCO}_{2}$ values with the sensor during the procedure. Statistically significant correlations were found between the values obtained by arterial blood gas analysis and sensor measurements (Figures 1 and 2).

The $\mathrm{TCSO}_{2}$ and $\mathrm{TCPCO}_{2}$ values measured and recorded by the sensor during FOB are summarized in Table 2. The mean $\mathrm{TCPCO}_{2}$ level was $37.09 \pm 5.6$ (27.160.6) $\mathrm{mmHg}$. The mean increase in the $\mathrm{TCPCO}_{2}$ level from baseline was $3.25 \pm 2.12 \mathrm{mmHg}$, and the maximum increase was $11.2 \mathrm{mmHg}$. The mean $\mathrm{TcSO}_{2}$ measurement was $95.9 \pm 2.27(80-100) \%$, and the

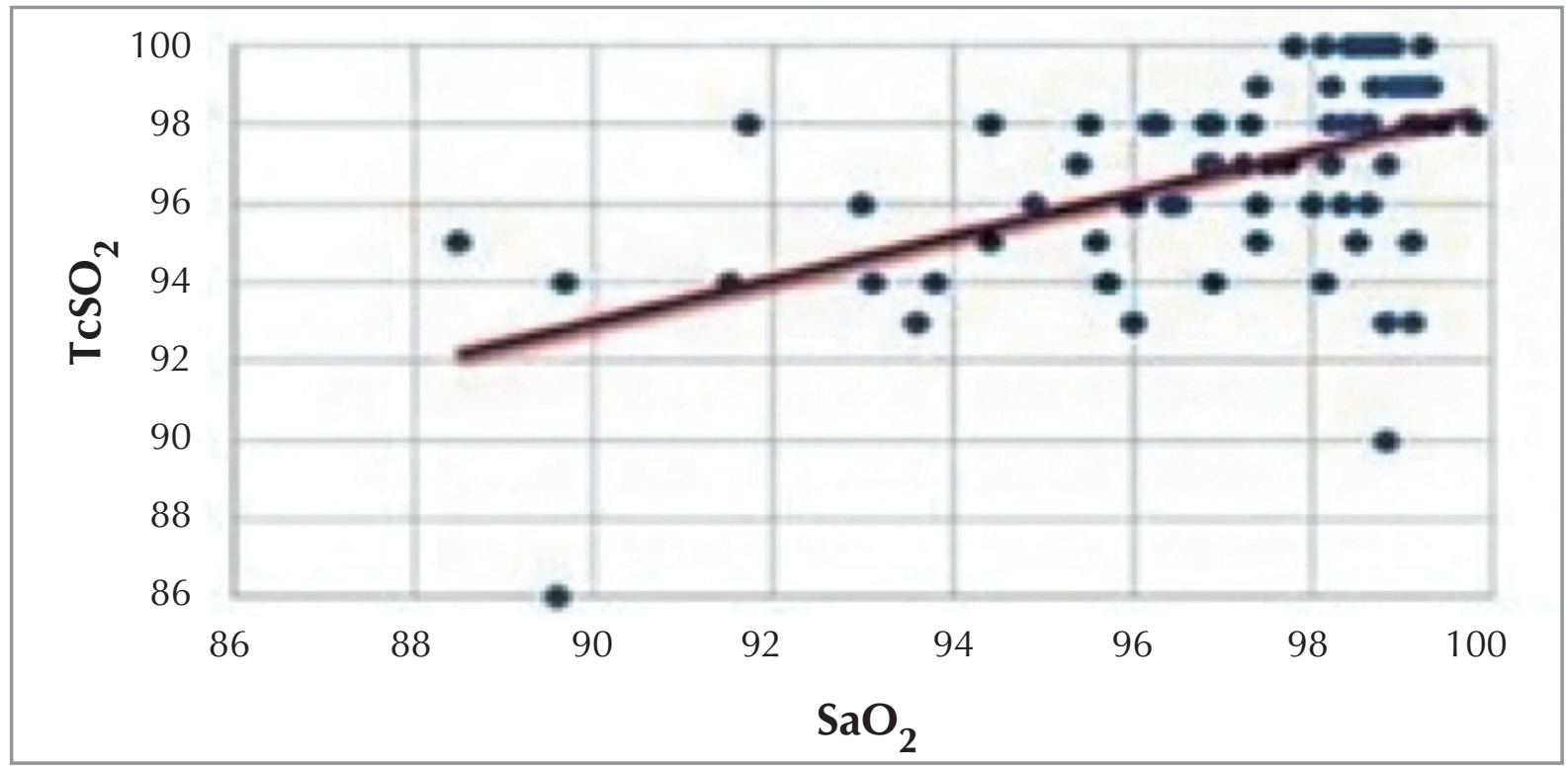

Figure 1. Scatter plot showing the correlation between $\mathrm{SaO}_{2}$ and $\mathrm{TcSO}_{2}(p<0.001, r=0.25)$. A linear regression analysis was performed to determine the correlation between $\mathrm{TcSO}_{2}$ and $\mathrm{SaO}_{2}$. 


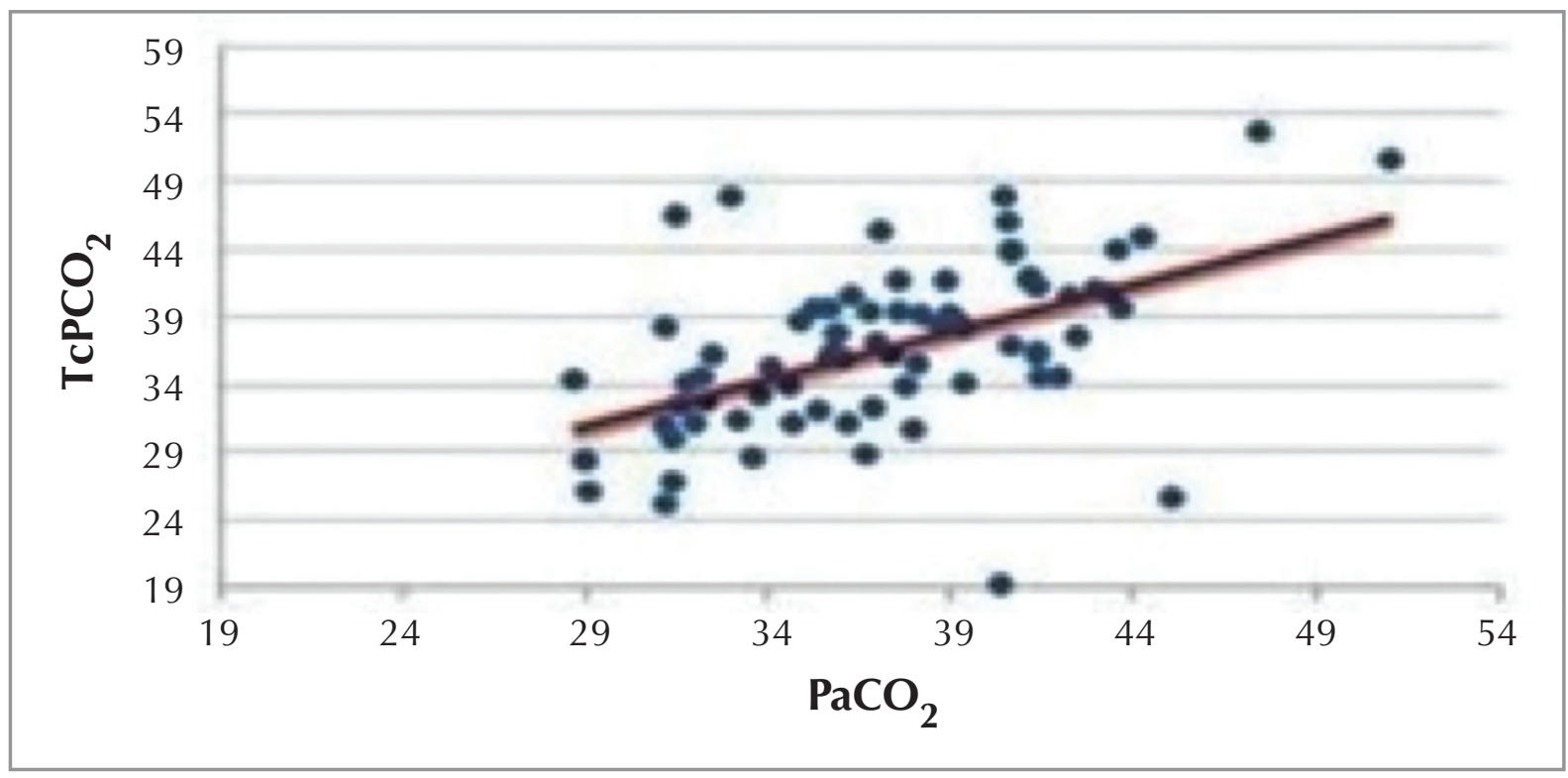

Figure 2. Scatter plot showing the correlation between $\mathrm{PaCO}_{2}$ and $\mathrm{TCPCO}_{2}(\mathrm{p}<0.001, \mathrm{r}=0.25)$. A linear regression analysis was performed to determine the correlation between $\mathrm{TCPCO}_{2}$ and $\mathrm{PaCO}_{2}$.

Table 2. $\mathrm{TCSO}_{2}$ and $\mathrm{TCPCO}_{2}$ values measured by the sensor during bronchoscopy

\begin{tabular}{|c|c|c|c|}
\hline & $\mathrm{TcPCO}_{2}\left(\mathrm{mmH}_{\mathrm{g}}\right.$ & & $\mathrm{TcSO}_{2}(\%)$ \\
\hline Mean* & $37.09 \pm 5.6$ & Mean* & $95.9 \pm 2.27$ \\
\hline Peak & 60.6 & Lowest & 80 \\
\hline Difference* & $3.25 \pm 2.12$ & Difference* & $5.11 \pm 3.17$ \\
\hline
\end{tabular}

mean decrease in $\mathrm{TcSO}_{2}$ during the procedure was $5.11 \pm 3.17(1-15) \%$.

An analysis was performed to determine the risk factors for developing hypoventilation, and the data are summarized in Table 3 and 4. The mean and peak $\mathrm{TcPCO}_{2}$ levels were significantly higher in males than in females ( $p=0.0027$ and $p=0.001$, respectively). Furthermore, the patients with a smoking history of more than 20 pack-years also had significantly higher $\mathrm{TCPCO}_{2}$ levels compared to the non-smokers and light smokers $(p=0.001)$. However, there was no significant relationship between the ventilation parameters and coexistent pleural effusion and COPD history. In the patients with endobronchial lesions, the decrease in the $\mathrm{TcSO}_{2}$ level during $\mathrm{FOB}$ was higher compared to those without endobronchial lesions ( $p=0.03)$, and the mean difference between the lowest and mean $\mathrm{TcSO}_{2}$ levels was significantly greater in the patients with endobronchial lesions (6.2 vs $4.55 \%, \mathrm{p}=0.03$ ).

The ROC analysis revealed that the optimal cut-off value for $\mathrm{FOB}$ duration in predicting hypoventilation was 15 minutes (AUC $=0.669,95 \%$ confidence interval: $0.546-0.791$ ) with a sensitivity of $89.7 \%$ and specificity of $33 \%$. We determined that the $\mathrm{FOB}$ duration being longer than 15 minutes and the presence of complex interventions, such as biopsy and brushing were associated with lower $\mathrm{TcSO}_{2}$ levels $(p=0.009$ and $p=0.04$, respectively). Although the association between the forced expiratory volume in one second $\left(\mathrm{FEV}_{1}\right)$ and ventilation parameters was statistically non-significant, the forced vital capacity was significantly related with lower peak and mean $\mathrm{TcPCO}_{2}$ values $(\mathrm{p}=0.01$ and $\mathrm{p}=0.03)$. 
Table 3. Mean and maximum $\mathrm{TcPCO}_{2}$ values according to the risk groups

\begin{tabular}{|c|c|c|c|c|}
\hline & Mean $\mathrm{TcPCO}_{2}(\mathrm{mmHg})$ & $\mathbf{p}$ & Maximum $\mathrm{TcPCO}_{2}(\mathrm{mmHg})$ & $\mathbf{p}$ \\
\hline \multicolumn{5}{|l|}{ Age } \\
\hline$\geq 65 y$ & $37.4 \pm 4.8$ & 0.90 & $40.2 \pm 5.3$ & 0.71 \\
\hline$<65$ y & $36.9 \pm 6$ & & $40.4 \pm 7$ & \\
\hline \multicolumn{5}{|l|}{ Gender } \\
\hline Female & $34.2 \pm 3.8$ & $0.0027^{*}$ & $37.2 \pm 3.9$ & $0.001 *$ \\
\hline Male & $38.5 \pm 5.8$ & & $41.8 \pm 6.8$ & \\
\hline \multicolumn{5}{|c|}{ Smoking (pack-years) } \\
\hline$\leq 20$ & $35.2 \pm 4.5$ & $0.001 *$ & $38 \pm 4.9$ & $0.002 *$ \\
\hline$>20$ & $39 \pm 6$ & & $42.6 \pm 6.9$ & \\
\hline \multicolumn{5}{|l|}{ COPD } \\
\hline Yes & $36.1 \pm 4.9$ & 0.5 & $39.4 \pm 4.9$ & 0.43 \\
\hline No & $37.4 \pm 5.8$ & & $40.6 \pm 6.7$ & \\
\hline \multicolumn{5}{|l|}{$\mathrm{FEV}_{1}(\%)$} \\
\hline$\geq 80$ & $35.7 \pm 4.8$ & 0.43 & $39 \pm 5.7$ & 0.38 \\
\hline$<80$ & $39.1 \pm 5.6$ & & $42.5 \pm 6.8$ & \\
\hline \multicolumn{5}{|l|}{ FVC (\%) } \\
\hline$\geq 80$ & $36 \pm 4.6$ & $0.03 *$ & $39 \pm 5.2$ & $0.01 *$ \\
\hline$<80$ & $38.7 \pm 5.9$ & & $42.2 \pm 7.1$ & \\
\hline \multicolumn{5}{|l|}{ PI. effusion } \\
\hline Yes & $37.8 \pm 6.5$ & 0.75 & $40.7 \pm 8.2$ & 0.52 \\
\hline No & $36.7 \pm 6$ & & $40.2 \pm 8.8$ & \\
\hline \multicolumn{5}{|l|}{ Duration } \\
\hline$\leq 15 \min$ & $36.5 \pm 5.3$ & 0.23 & $39.2 \pm 5.8$ & 0.32 \\
\hline$>15 \mathrm{~min}$ & $37.5 \pm 5.8$ & & $41 \pm 6.7$ & \\
\hline \multicolumn{5}{|l|}{$\mathrm{EBL}$} \\
\hline Yes & $37.9 \pm 5.4$ & 0.33 & $41.3 \pm 5.5$ & 0.36 \\
\hline No & $36.7 \pm 5.7$ & & $39.8 \pm 6.8$ & \\
\hline \multicolumn{5}{|l|}{ Intervention } \\
\hline Complex & $37.4 \pm 5.7$ & 0.33 & $40.8 \pm 6.4$ & 0.48 \\
\hline Simple & $36.4 \pm 5.4$ & & $39.3 \pm 6.3$ & \\
\hline
\end{tabular}

\section{DISCUSSION}

The use of non-invasive methods to determine the $\mathrm{SpO}_{2}$ and $\mathrm{PCO}_{2}$ levels compared to the arterial blood gas analysis has numerous advantages, including less complications and continuous recording of measurements. In particular, the risk of hypoventilation is increased in interventions with a long duration. Hypoventilation during interventions is a multifactorial issue that can occur through several mechanisms, including upper airway obstruction, alveolar hypoventilation secondary to sedatives given just before the procedure, and ventilation-perfusion mismatch caused by the intervention itself (2). Current guidelines recommend sedation before bronchoscopy in order to improve patient comfort and reduce complications (11). However, the use of sedatives alone or in combination can cause hypoventilation. In our clinic, we premedicate patients only with low dose of midazolam and local lidocaine. Obesity is another important reason for hypoventilation, and therefore we excluded patients with a BMI of $\geq 30$ from our sample. The best indicator of hypoventilation is an increased $\mathrm{PaCO}_{2}$ level, and $\mathrm{SaO}_{2}$ alone is not sufficient to assess ventilation (3).

The British Thoracic Society (BTS) guidelines warn clinicians to be careful about respiratory insufficien- 
Table 4. Mean and minimum $\mathrm{TCSO}_{2}$ values according to the risk groups

\begin{tabular}{|c|c|c|c|c|}
\hline & Mean $\mathrm{TcPCO}_{2}(\mathrm{mmHg})$ & $\mathbf{p}$ & Maximum $\mathrm{TcPCO}_{2}(\mathrm{mmHg})$ & $\mathbf{p}$ \\
\hline \multicolumn{5}{|l|}{ Age } \\
\hline$\geq 65 y$ & $95.7 \pm 2.7$ & 0.44 & $89.9 \pm 4.5$ & 0.14 \\
\hline$<65$ y & $96.1 \pm 2$ & & $91.4 \pm 4.1$ & \\
\hline \multicolumn{5}{|l|}{ Gender } \\
\hline Female & $95.3 \pm 2.5$ & 0.08 & $90 \pm 4.5$ & 0.73 \\
\hline Male & $96.3 \pm 2.1$ & & $91.2 \pm 4.2$ & \\
\hline \multicolumn{5}{|c|}{ Smoking (pack-years) } \\
\hline$\leq 20$ & $95.9 \pm 2.3$ & 0.84 & $90.9 \pm 4.3$ & 0.91 \\
\hline$>20$ & $96 \pm 2.3$ & & $90.8 \pm 4.3$ & \\
\hline \multicolumn{5}{|l|}{ COPD } \\
\hline Yes & $95 \pm 2.7$ & 0.07 & $89 \pm 5.5$ & 0.05 \\
\hline No & $96.2 \pm 2.1$ & & $91.3 \pm 3.8$ & \\
\hline \multicolumn{5}{|l|}{$\mathrm{FEV}_{1}(\%)$} \\
\hline$\geq 80$ & $95.4 \pm 2$ & 0.06 & $90.4 \pm 3.7$ & 0.71 \\
\hline$<80$ & $96.1 \pm 2.3$ & & $90.7 \pm 4.7$ & \\
\hline \multicolumn{5}{|l|}{ FVC (\%) } \\
\hline$\geq 80$ & $95.5 \pm 2.3$ & 0.38 & $90.6 \pm 4$ & 0.59 \\
\hline$<80$ & $96 \pm 2.1$ & & $90.5 \pm 4.5$ & \\
\hline \multicolumn{5}{|l|}{ Pl. effusion } \\
\hline Yes & $95.7 \pm 2.4$ & 0.65 & $90.1 \pm 4.8$ & 0.37 \\
\hline No & $95.8 \pm 2.2$ & & $90.8 \pm 4.4$ & \\
\hline \multicolumn{5}{|l|}{ Duration } \\
\hline$\leq 15 \min$ & $96.3 \pm 1.8$ & 0.15 & $92.2 \pm 4$ & $0.009 *$ \\
\hline$>15$ min & $95.7 \pm 2.5$ & & $90 \pm 4.3$ & \\
\hline \multicolumn{5}{|l|}{$\mathrm{EBL}$} \\
\hline Yes & $95.3 \pm 2.9$ & $0.01 *$ & $89.1 \pm 5.4$ & $0.03 *$ \\
\hline No & $96.2 \pm 1.8$ & & $91.7 \pm 3.4$ & \\
\hline \multicolumn{5}{|l|}{ Intervention } \\
\hline Complex & $95.6 \pm 2.4$ & $0.04^{*}$ & $90.3 \pm 4.5$ & 0.13 \\
\hline Simple & $96.7 \pm 1.9$ & & $91.9 \pm 3.9$ & \\
\hline
\end{tabular}

cy signs during bronchoscopy, especially in oxygen supported cases in which carbon dioxide retention can develop even if $\mathrm{SaO}_{2}$ is within the confident interval (5). The highest tolerable $\mathrm{PaCO}_{2}$ level during $\mathrm{FOB}$ is not known. In patients with severe COPD, sedation can cause carbon dioxide retention (12). Respiratory complications associated with FOB are more common in patients with severe COPD (13). In our study, 16 patients had COPD, and 11 of these patients were found to have $<50 \% \mathrm{FEV}_{1}$. However, there was no statistically significant difference between the patients with and without COPD in terms of ventilation parameters. This may be because before the procedure, we treated these patients with nebules in order to prevent possible bronchospasm. In addition, as the BTS guidelines recommend, we performed continuous monitorization of the patients and provided controlled oxygen support throughout FOB.

Since an arterial blood gas analysis shows the instant values of ventilation, monitoring of ventilation during the whole procedure is not possible. Therefore, recently, one of the main goals is to develop new techniques to monitor $\mathrm{PCO}_{2}$ levels. The end-tidal carbon dioxide pressure measurement is another technique to monitor ventilation, which is well correlated with $\mathrm{PaCO}_{2}$ in intubated patients $(10,14)$. 
However, during endoscopic procedures, some factors, including involuntary patient movements, cough, and ventilation switch between the nose and mouth can cause artefacts in end-tidal carbon dioxide values or false interpretations (10). In 1951, it was shown that when the skin reached the highest tolerable temperature $\left(45^{\circ} \mathrm{C}\right)$, the skin blood flow increased and the surface oxygen level reached the arterial oxygen level (15). Since then, some transcutaneous devices have been developed to monitor carbon dioxide and oxygen level simultaneously using small clips placed on the distal parts of the body, such as the earlobes (16). Studies have demonstrated that transcutaneously measured $\mathrm{TCPCO}_{2}$ values are well correlated with $\mathrm{PaCO}_{2}$ values measured by an arterial blood gas analysis (17-19). Similarly, in our study, the statistical analysis revealed a correlation between the $\mathrm{TCPCO}_{2}$ values measured by the sensor and the arterial blood $\mathrm{PaCO}_{2}$ levels.

Previous studies monitoring $\mathrm{PCO}_{2}$ and $\mathrm{SpO}_{2}$ during FOB showed that the $\mathrm{PCO}_{2}$ levels increased during this procedure $(1,3)$. The authors interpreted this increase in $\mathrm{PCO}_{2}$ levels as an early sign of respiratory depression. In our study, we found that the mean and peak $\mathrm{TCPCO}_{2}$ values were higher in men compared to women $(p=0.0027)$. Certain factors, including a smoking history and presence of a mass on imaging are more common in men, which must may also be the reason why respiratory depression signs are more common in this group. Smoking is associated with the worsening of ventilation and some respiratory symptoms that are increasing with the number of packyears (20). In the present study, it was found that the mean $\mathrm{TCPCO}_{2}$ was higher in the patients with a history of smoking more than 20 pack-years $(p=0.002)$.

According to our results, the patients with masses in their imaging findings $(n=36)$ had statistically significantly lower mean and lowest $\mathrm{TcSO}_{2}$ values than those without any mass $(p=0.01$ and $p=0.008$, respectively). It is also notable that the difference between the mean and lowest $\mathrm{TcSO}_{2}$ values was higher in the patients with endobronchial lesions than those without these lesions $(6.20 \pm 3.50$ vs. 4.55 $\pm 2.87 \%, p=0.03)$. Credle et al. determined that major complications and mortality rates of FOB were fairly rare at 0.08 and $0.01 \%$, respectively. Most cases seem to be preventable, and therefore proper monitorization is essential. Premedication and topical anesthesia dosage must be restricted in order to avoid respiratory depression or systemic toxicity (21).
In 2006, Chhajed et al. assessed the association between the $\mathrm{FOB}$ duration and $\mathrm{PCO}_{2}$ levels. The authors reported that there was no significant relationship between the FOB duration and increased $\mathrm{PCO}_{2}$ levels (3). According to our results, although the $\mathrm{TCPCO}_{2}$ values were higher in the patients whose procedure lasted longer than 15 minutes, the difference was statistically non-significant (41.01 vs. 39.24 $\mathrm{mmHg}, \mathrm{p}=0.32$ ). In the patients with FOB duration of more than 15 minutes, the mean $\mathrm{TcSO}_{2}$ was lower, and the difference between the mean and minimum $\mathrm{TcSO}_{2}$ values was higher $(\mathrm{p}=0.009$ and $\mathrm{p}=0.01$, respectively).

\section{CONCLUSION}

It is not easy to detect patients at higher risk of developing hypoventilation during FOB. The pathophysiology underlying hypoventilation during FOB is multifactorial. $\mathrm{PCO}_{2}$ remains the best indicator of ventilation, and it is clear that monitorization of $\mathrm{PCO}_{2}$ is essential to detect hypoventilation.

Our results support the feasibility of the transcutaneous measurements of $\mathrm{PCO}_{2}$ and $\mathrm{SpO}_{2}$. We identified male gender, presence of endobronchial lesions, heavy smoking, and longer FOB duration (>15 min) as risk factors for developing hypoventilation during the procedure. We consider it essential that patients with these risk factors are monitored for $\mathrm{SpO}_{2}$ and $\mathrm{PCO}_{2}$ during $\mathrm{FOB}$. However, larger and prospective studies are needed to confirm our results.

Ethical Committee Approval: The approval for this study was obtained from institutional review board committee of University of Health Sciences, Diskapi Research and Training Hospital, Ankara (Decision no: 33.02 Date: 12.12.2016).

\section{CONFLICT of INTEREST}

The authors of this manuscript declare that they have no conflict of interest.

\section{AUTHORSHIP CONTRIBUTIONS}

Concept/Design: MYS, HF

Analysis/Interpretation: MYS

Data Acquisition: MYS

Writting: MYS

Critical Revision: HF, EBK

Final Approval: MYS, HF, EBK 


\section{REFERENCES}

1. Evans E, Ganeshalingam K, Ebden P. Changes in oxygen saturation and transcutaneous carbon dioxide and oxygen levels in patients undergoing fibreoptic bronchoscopy. Respir Med 1998; 92(5): 739-42.

2. Chhajed PN, Glanville AR. Management of hypoxemia during flexible bronchoscopy. Clin Chest Med 2003; 24(3): 511-6.

3. Chhajed PN, Rajasekaran R, Kaegi B, Chhajed TP, Pflimlin $E$, Leuppi J, et al. Measurement of combined oximetry and cutaneous capnography during flexible bronchoscopy. Eur Respir J 2006; 28(2): 386-90.

4. Fu ES, Downs JB, Schweiger JW, Miguel RV, Smith RA. Supplemental oxygen impairs detection of hypoventilation by pulse oximetry. Chest 2004; 126(5): 1552-8.

5. Du Rand IA, Blaikley J, Booton R, Chaudhuri N, Gupta V, Khalid S, et al. British Thoracic Society guideline for diagnostic flexible bronchoscopy in adults: accredited by NICE. Thorax 2013; 68 Supp/ 1: i1-i44.

6. Gursel G. Respiratory monitoring during mechanical ventilation: II. Tuberk Toraks 2003; 51(1): 100-6.

7. Sanders MH, Kern NB, Costantino JP, Stiller RA, Strollo PJ, Studnicki KA, et al. Accuracy of end-tidal and transcutaneous PCO2 monitoring during sleep. Chest 1994; 106(2): 472-83.

8. Stege G, Van Den Elshout FI, Heijdra YF, Van De Ven MI, Dekhuijzen PR, Vos PJ. Accuracy of transcutaneous carbon dioxide tension measurements during cardiopulmonary exercise testing. Respir 2008; 78(2): 147-53.

9. Urbano J, Cruzado V, López-Herce J, del Castillo J, Bellón JM, Carrillo Á. Accuracy of three transcutaneous carbon dioxide monitors in critically ill children. Pediatric Pulmonol 2010; 45(5): 481-6.

10. Heuss LT, Chhajed PN, Schnieper P, Hirt T, Beglinger C. Combined pulse oximetry/cutaneous carbon dioxide tension monitoring during colonoscopies: pilot study with a smart ear clip. Digestion 2004; 70(3): 152-8.

11. Kar Kurt Ö, Talay F, Karğı A, Yaşar Z, Tuğ T. Sedation for fiberoptic bronchoscopy: review of the literature. Tuberk Toraks 2015; 63(1): 42-7.
12. Committee BTSBG. British Thoracic Society guidelines on diagnostic flexible bronchoscopy. Thorax 2001; 56 (suppl 1): i1-i21.

13. Bellinger $C R$, Khan I, Chatterjee AB, Haponik EF. Bronchoscopy safety in patients with chronic obstructive lung disease. J Bronchology Interv Pulmonol 2016; 24(2): 98-103.

14. Miner JR, Heegaard W, Plummer D. End-tidal carbon dioxide monitoring during procedural sedation. Academic emergency medicine: Soc Emerg Med 2002; 9(4): 27580.

15. Baumberger J, Goodfriend R (eds). Determination of arterial oxygen tension in man by equilibration through intact skin. Federation Amer Soc Exp Biol Med 20814-3998. Federation Proceedings; 1951, 9650 Rockville Pike, Bethesda.

16. Bernet-Buettiker V, Ugarte MJ, Frey B, Hug MI, Baenziger $O$, Weiss M. Evaluation of a new combined transcutaneous measurement of $\mathrm{PCO}_{2}$ /pulse oximetry oxygen saturation ear sensor in newborn patients. Pediatrics 2005; 115(1): e64-e8.

17. Storre JH, Magnet FS, Dreher $M$, Windisch $W$. Transcutaneous monitoring as a replacement for arterial $P C O(2)$ monitoring during nocturnal non-invasive ventilation. Respir Med 2011; 105(1): 143-50.

18. Chhajed PN, Kaegi B, Rajasekaran R, Tamm M. Detection of hypoventilation during thoracoscopy: combined cutaneous carbon dioxide tension and oximetry monitoring with a new digital sensor. Chest 2005; 127(2): 585-8.

19. Chhajed PN, Langewitz W, Tamm M. (Un) explained hyperventilation. Respiration 2006; 73(6): 825.

20. Isabel U, Alberto C, María QJ, Nerea M, Xavier B, Jordi S. Smoking habit, respiratory symptoms and lung function in young adults. Eur J Health 2005; 15(2): 160-5.

21. Credle Jr WF, Smiddy JF, Elliott RC. Complications of fiberoptic bronchoscopy 1-3. Am Rev Respir Dis 1974; 109(1): 67-72. 